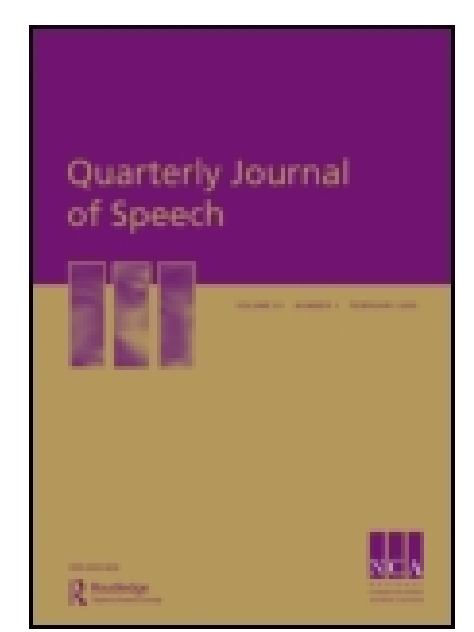

Quarterly J ournal of Speech

ublication details, including instructions for authors and subscription information:

http:// www.tandfonline.com/loi/ rajs20

\title{
The rhetorical principles of Cicero and Adams
}

ousene G. Rousseau ${ }^{\text {a }}$

Western State Normal School, Kalamazoo, Michigan

Published online: 05 J un 2009.

To cite this article: Lousene G. Rousseau (1916) The rhetorical principles of Cicero and Adams, Quarterly J ournal of Speech, 2:4, 397-409, DOI: 10.1080/00335631609360567

To link to this article: http:// dx. doi.org/ 10.1080/00335631609360567

PLEASE SCROLL DOWN FOR ARTICLE

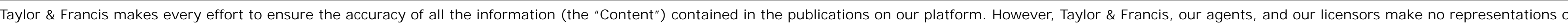

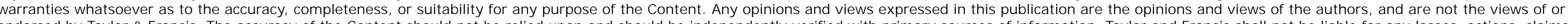

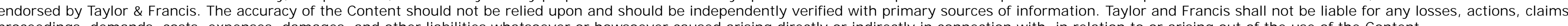
proceedings, demands, costs, expenses, damages, and other liabilities whatsoever or howsoever caused arising directly or indirectly in connection with, in relation to or arising out of the use of the Content.

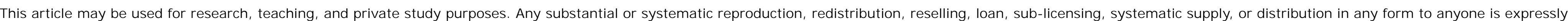
forbidden. Terms \& Conditions of access and use can be found at http://www.tandfonline.com/page/terms-and-conditions 


\section{THE RHETORICAL PRINCIPLES OF CICERO AND}

ADAMS

LOUSENE G. ROUSSEAU

Western State Normal School, Kalamazoo, Michigan

A

LTHOUGH a period of almost eighteen centuries separated

the great Latin orator, Cicero, and the great American statesman, John Quincy Adams, they were in one respect enough alike to make a comparison between them rather interesting.

The basis of this comparison is to be purely rhetorical principles. Cicero's treatise in three books, De Oratore, and Adams' Lectures on Rhetoric and Oratory, delivered during the three years (I806I809) when he held the Boylston chair of rhetoric at Harvard, form the basis of this discussion.

In such a comparison, we must bear in mind constantly the fact that Cicero's treatise is a carefully prepared exercise, and that Adams has delivered his lectures by word of mouth. For this reason connections are not always as clear as though Adams had written his lectures in the form of a book.

When we consider the important place that oratory once occupied, the great number of famous orators who have lived, and the great profusion of writings on rhetoric and oratory, we would expect to find a treatise written in the nineteenth century to cover a wide field, and represent the ideas of many authors. Such is not the case, however.

Adams had a genuine respect, not only for Cicero, but for all ancient authors. At one time he says, "The immeasurable superiority of ancient over modern oratory is one of the most remarkable circumstances, which offer themselves to the scrutiny of reflecting minds." Again he says, "Call up the shades of Demosthenes and Cicero to vouch your words; point to their immortal works, and say, these are not only the sublimest strains of oratory, that ever issued from the uninspired lips of mortal men; they are at the same time the expiring accents of liberty in the nations, which have shed the brightest lustre on the name of man."

${ }^{1}$ John Quincy Adams, Lectures on Rhetoric and Oratory, 2 Vols., (Cambridge, 1810), Vol. I, p. 98.

Adams, I, p. 22. 
This tremendous admiration for the oratory of the ancients was largely concentrated on Cicero and Quintilian. "And in them alone are we to seek for all that Roman literature can furnish to elucidate the science of rhetoric.",

Cicero, however, was the chief favorite. Constantly he is held up as the perfect model for his students to copy, the perfect orator, the logical rhetorician, the great teacher. No praise is too high for him. ". . . His rhetorical works have a recommendation to the student beyond all others; because they are the lessons of a consummate master on his own art. His theory holds a flambeau to his practice, and his practice is a comment on his theory." "4

The first point made in both treatises is relative to the importance of public speaking. Both men agree in elevating rhetoric and oratory to the highest pinnacle of fame. "In the flowery periods of Greece and Rome," Adams exclaims, "eloquence was Power. It was the instrument and spur to ambition. The talent of public speaking was the key to the highest dignities; the passport to the supreme dominion of the state. The voice of oratory was the thunder of Jupiter." "Wh we look back to see what Cicero says on this subject, we find him exclaiming in the same strain, "Or what is so striking, so astonishing, as that the religious feelings of judges, the gravity of the senate, should be swayed by the speech of one man?"'

Here we must remember that it was only natural for Cicero to extol oratory so highly, for he was primarily an orator. Adams, however, could not have appreciated it quite so highly, for his interests did not lie in that direction. Hence it is quite likely that he has caught a little of his enthusiasm from the study of Cicero.

From this point, both men turn to a justification of oratory. Both state the same objections to that science or art, and what is more, they both answer the same objections in the same way. According to Cicero, the first objection generally made to the study of rhetoric is that it is full of scholastic stuff not useful for an orator." Adams quotes it as "a pedantic science, overcharged with

${ }^{3}$ Ibid., I, p. I40.

Ibid., I, p. 98.

'Ibid., I, p. I9.

- Cicero, Oratory and Orators (London, I909), p. I5I.

${ }^{8}$ Cicero, p. 165. 
scholastic subtleties oppressive to genius, and never practicable." Cicero answers this argument by the statement that all this is necessary; this knowledge is the tools the orator works with; that he is never ignorant by what means he attains his end. ${ }^{\circ}$ Adams answers it in the same way. "It is necessary to know the tools you work with in rhetoric as much as in any profession."”

As the second and third arguments are very similar and just as much alike, we will not waste time quoting them. This first point is sufficient to show that Adams follows the same line of thought as Cicero.

Now we come to the first instance of opposition between the two men. This is when each attempts to define oratory. Here we would naturally expect Adams to copy from Cicero, since the latter was so much a master of his art, but such is not the case. Cicero insists that oratory is not an art, and Adams maintains that it is. At one time Cicero says, "Although oratory is not an art, no excellence is superior to that of a consummate orator" ${ }^{10}$ and again, "Therefore- eloquence has not sprung from art, but art from eloquence." "11

Adams, on the contrary, is very decisive in his assertion that oratory is an art. "If we accept Quintilian's definition of rhetoric, we may apply it to oratory, only that it is the art, not the science of speaking well." ${ }^{, 12}$ To him, there is no doubt whatever that oratory is an art. In this argument, Cicero and Adams are quite opposed.

Next, we will consider the general preparation necessary for an orator. Cicero maintains a very rigid standard for him. In addition to becoming a perfect speaker, which in itself is no small task, he would require the student to become learned in all subjects, so that he would never be at a loss for something to say on any subject. "In my opinion," he says, "no man can be an orator possessed of every praiseworthy accomplishment, unless he has attained the knowledge of everything important, and of all liberal arts, for his language must be ornate and copious from knowledge, since, unless there be beneath the surface, matter understood and felt by the

\footnotetext{
8 Adams, I, p. 54.

${ }^{9}$ Ibid., I, p. 59.

${ }^{10}$ Cicero, p. 229.

II Ibid., p. I79.

${ }^{12}$ Adams, I, p. $4 \mathrm{I}$.
} 
speaker, oratory becomes an empty and almost puerile flow of words." Again, "It is necessary for a good orator to have heard and seen much, to have gone over many subjects in thought and reflection, and many also in reading, though not so as to have tasted of them as things belonging to others. For I confess that the orator should be a knowing man, not quite a novice or tiro in any subject, not utterly ignorant or inexperienced in any business of life."'14 In a word, the speaker must know everything if he is to deliver a speech, "weighty, agreeable, savouring of erudition and liberal knowledge, worthy of admiration, polished, having feeling and passion in it." ${ }^{15}$ Such a man must certainly be a past master in all the arts and sciences.

Adams does not in any place directly agree or disagree with Cicero. His general feeling on this point, however, seems to be rather in favor of a thorough mastery of only the art of oratory, plus some law. He says constantly that patience and persistence and a thorough mastery of the laws of rhetoric will always produce a good speaker.

In this point, the general preparation of an orator, we find that Cicero is more exacting and requires much more study on the part of the speaker, while Adams is content to have his orator master only rhetoric.

After this we find both men arranging a division of their subjects. Here we conclude that the same divisions have continued since the time of Cicero, for Adams has made no change. The older man explains his divisions thus- "All the business and art of an orator is divided into five parts: he ought first to find out what he should say (invention), next, to dispose and arrange his matter, not only in a certain order, but with a sort of power and judgment (disposition), next, to clothe and deck his thoughts with language (embellishment), then to secure them in his memory (memory), and lastly, to deliver them with dignity and grace (delivery).,16

In conformance with this division, Adams adopts the same plan. He divides his subject into five parts, invention, disposition, elocu-

\footnotetext{
${ }^{13}$ Cicero, p. I47.

${ }^{14}$ Ibid., p. 203.

${ }^{15}$ Ibid., p. 359.

${ }^{16}$ Cicero, p. I78.
} 
tion, memory, and pronunciation, or action. ${ }^{17}$ These divisions are the same, both in title and substance, as the divisions of Cicero, and it is not unjust to Adams to claim that he copied from Cicero here as well as in many other places.

Not content with copying the divisions, Adams goes one step further, and copies his definitions of these parts from the same source. Here, however, he has the grace to acknowledge his source. Here are his definitions, word for word alike in both volumes:

"Invention is the discovery by thought of those things, the truth or verisimilitude of which renders the cause probable.

"Disposition is the orderly arrangement of the things invented.

"Elocution is the application of proper words and sentences to invention.

"Memory is the firm perception by the mind of the things and words applied to invention. And

"Pronunciation is the management of the voice and body, conformably to the dignity of the words and things.",18

Classifications seem to be in order in rhetoric as in everything else, and we find that the next point to consider is the classification of the kinds of oratory. We might think that in the course of eighteen hundred years, oratory would have taken on new phases and branched out in different lines. When we come to the classifications and definitions of Adams, however, we find that either oratory has remained practically the same for centuries, or Adams paid no attention to the changes that did occur.

Cicero says that there are different styles of oratory for judicial proceedings, deliberations, panegyrics, and common narration or conversation. ${ }^{19}$

Adams bases his classification along the same line of thought, but in a more elaborate manner. First, he says, there is deliberative oratory. ${ }^{20}$ Here he adds nothing to what Cicero says of 1 t.

Demonstrative oratory is the second class. Here he includes more than Cicero, who makes demonstrative consist of only the panegyrics. Adams says that panegyrics are one class of demon-

\footnotetext{
${ }^{17}$ Adams, I, p. I62.

${ }^{18}$ Adams, I, p. I63. Cicero, pp. I78-179.

${ }^{19}$ Cicero, p. 395.

${ }^{20}$ Adams, I, p. 178.
} 
strative oratory, but that the class embraces more than that, and I believe he is right.

Adams next goes to a discussion of judicial oratory. As far as Cicero goes in this discussion, the Harvard man agrees with him. Then he proceeds to make a few additions on his own initiative. He subdivides judicial oratory into the eloquence of the bench. Under this division, he includes the charges of magistrates to grandjuries, their addresses to petit-juries on summing up causes, and the assignment of reasons which they often give for their decisions. ${ }^{21}$ The discussion here is rather lame, as though Adams. had almost convinced himself that his point was not important. It may be an attempt on his part to make his course apply to modern oratory in some degree, or it may be simply an insertion for the sake of originality. At any rate, these pages do not fit in at all with the rather scholarly and studied lectures.

We will now proceed to the discussion of these classifications. First, we come to the study of deliberative oratory. Here, Adams copied very little from Cicero, because the latter has not delivered a very weighty treatise on this division. One statement that we find in the Lectures is rather puzzling. Adams states that the deliberative passion is jealousy; the judicial passion, avarice; and the passion of the pulpit orator, fear. ${ }^{22}$ What he can mean by such a statement is doubtful. He has not copied this idea from Cicero, because that great orator does not in any place attempt to assign any particular passion to any kind of oratory. The statement is so peculiar, and so extremely old-fashioned in sound, that it is very likely that Adams has copied it from some other ancient source, without any acknowledgement, as he so often does.

Under this subject, Adams discusses the arguments of contingency, necessity, facility, probability, possibility, and legality. The main consideration here is sincerity, secured by simplicity. The purpose of this kind of oratory is to move to action. The suggestions here are all good; most of them are recommended by the best teachers of public speaking today. Further than that, there is nothing to say about this chapter.

\footnotetext{
Adams, I, p. I8I.

${ }^{22}$ Ibid., I, p. 384-387.
} 
In connection with this point, Adams has an idea which is peculiar enough to make it worth while to state it here. It seems that, if you follow his advice, you will first size up your audience, if I may use that expression. If the majority of your hearers are uneducated, ignorant, rude, you will present images of gain, of emolument, of thrift, of pleasure. If, on the other hand, your audience is rather educated, civilized, and honorable, you will enlarge especially upon topics of praise, honor, and virtue. Not only does Adams repeat here what Cicero says, giving him full credit for it, but he heartily recommends it. "This passage of Cicero. - . I recommend to your meditations as the truly paternal advise of a father to his child. You will find it not only a most useful guide in the practice of deliberative oratory, but . . . it will furnish you a measure for many an audience and many a speaker.",2s

Another interesting bit of advice comes in this connection, and Adams again gives Cicero credit for the thought. He says that the eloquence of deliberation will necessarily take much of its color from the orator himself. Now comes the interesting part. While the orator is still young, "airy splendor of style and unaffected modesty of address" will characterize his speech; if he is older, and more elevated in dignity" and reputation, "the gravity of his manner and the weight of sentiment should justly correspond with the reverence due to his station." ${ }^{24}$ In other words, the age of the orator will determine his mode of address.

These ideas are not prevalent now, and were not popular at the time these lectures were delivered. The only explanation for their presence on these pages is that Adams was unduly influenced by Cicero, and so copied many things he would not have thought of copying if his work had not been so entirely based on one source.

The second division of oratory is the demonstrative class. Under this, Adams groups all those orations that are ultimately intended for show. The chief demonstrative discourse in his estimate, and the only one worth mentioning, in Cicero's opinion, is the panegyric. In a long preamble, Adams laments the fact that the panegyric has had so little fame in England, and is so slightly used

${ }^{23}$ Adams, I, p. 264.

${ }^{24}$ Ibid., I, p. 268. 
in the United States. He declares that it is too great a form, and too valuable to be neglected the way it is. The ancients realized the value of it, as any one would know who has read Cicero's great panegyrics. Because it is so valuable, it is worth rather careful discussion, he reasons. ${ }^{25}$

Here I believe that Adams either did not read what Cicero has to say about the panegyric, or misinterpreted it, for, although Cicero did deliver some very wonderful panegyrics, he considered them as deserving of only slight mention in his Oratore, because the principles involved here were about the same as for the other kinds of oratory. Again he says, "We of this country are not accustomed to deal much in panegyric,"26 which would seem to contradict directly what Adams says. The latter, however, continues his discussion, under the impression that he is uttering the sentiments of the great master himself. He goes into great detail about the two kinds of panegyric, biographical and ethical, and says that the latter kind is more favored by Cicero. Then he states the rules one must follow in writing a formal panegyric.

Here it seems to me that Adams has definitely attempted to follow Cicerro, but that he has failed, probably because he judged the latter's ideas on the subject from the speeches he gave, rather than from the treatise he wrote on the subject.

The third kind of oratory, as we have already seen, is the oratory of the bar, or judicial oratory. To Cicero, most all oratory flavored of the judicial. In his time, all of the great orations were delivered before a crowded assembly, which acted as the judge, or before the assembled multitude, as when a funeral oration was given. Thus the deliberative speech became also a judicial speech, and this division then covered all but the panegyric. In the course of eighteen hundred years, too, the judicial system has become so entirely changed that there is scarcely any common ground for comparison here.

The last kind of oratory, pulpit oratory, is again a subject on which there is no common basis of comparison. The advent of Christianity has completely changed the religious ideals of the world. The establishment of a definitely organized church, and,

\footnotetext{
${ }^{28}$ Adams, I, p. 238.

${ }^{28}$ Ibid., I, p. 323 .
} 
still later, of many organized churches, made such a complete change in the world that there is no comparison to be made.

To leave this part of the subject, let us proceed at once to the discussion of the parts of the discourse. Here there is a peculiar thing to notice. Adams quotes Cicero, and seems to think that he is following him, while in reality, Cicero has not the same idea at all.

Cicero says that the proper division of a subject is "First, to premise it before we come to the point; then to explain the matter in question; then to support it by strengthening our own arguments, and refuting those on the other side; next, to sum up, and come to the peroration." ${ }^{27}$ However, he says that these divisions are used only for convenience; that they are not the best that can be made, etc.; but he considers them of minor importance, and therefore does not stop to better them. He says: "Nor do I altogether condemn these divisions; for they are made with some nicety, though without sufficient judgment as must of necessity be the case with men who had no experience in real pleading.,"28

Such things as these Adams overlooked, or purposely chose to ignore, for he says that the distinct parts of the discourse, according to Cicero, are six: introduction, narration, proposition, confirmation, confutation, and conclusion. ${ }^{29}$

The first part of the discourse is the exordium. This term is not used to a large extent now, but Cicero used it, therefore Adams must needs do the same. Cicero says that the exordium is a "discourse to prepare the minds of the audience for the favourable reception of the remainder,"30 and Adams accepts his word for it. Continuing, the discussion is so similar in both books that it is not worth while to waste time quoting it. One thing only is noteworthy here. Adams says that in order to gain the good-will of the audience, the speaker must first make allusions to himself; second, explain his motives; then make professions of honor and virtue; then disprove or extenuate charges or inculpations which may have been alleged against him; then lead the minds of the hearers to recollections of his services or good deeds; next, to enlarge on difficulties, obstacles,

${ }^{27}$ Cicero, p. 3 I3.

${ }^{28}$ Ibid., p. 397.

${ }^{29}$ Adams, I, p. 397.

${ }^{30}$ Ibid., I, p. 399. 
and dangers with which he has contended; and at the very end, express open solicitation. ${ }^{31}$

Altogether this is not copied directly from anything in the Oratore, I feel confident that Adams has copied this from some ancient rhetorician, for the sentiment expressed here is that of the ancient orators. Adams himself never made use of this principle in his speeches, and there is no reason why we should think that he believed it. This is only another example of how much Adams copied.

Proposition and partition follow this logically. So far as the proposition is concerned, both men are agreed that it is absolutely necessary. "Whatever you advance should be laid down as a proposition," ${ }^{32}$ says Cicero. "The proposition," says Adams, "is indispensable." ${ }^{\text {p3 }}$

The entire discussion of this part, and the related subject, partition is alike in both books. Adams even accepts the rules that Cicero lays down for determining the composition of these forms.

The discussion of topics, the next division, is long and tiresome, and very similar, with the exception that Adams gives a more detailed division of the subject than Cicero. When we investigate this a little further, we find that this division is of Quintilian origin, so that we can still consider Adams guilty of copying.

Narration, the fourth division, is not accorded a very thorough discussion in either text, and we need not go into it here.

When we come to the proof, we find both men growing eloquent. The discussion is long and heated, but there is nothing so striking that it should be quoted. While they agree in general, Cicero is more scholarly, and goes more deeply into the question. Adams has one or two small additions to make, and otherwise seems to model his discussion after Cicero.

Amplification is the topic that pleases Cicero most, and accordingly Adams is also very much interested in it. The former becomes quite eloquent when he discusses this. "But the greatest glory of eloquence is to exaggerate a subject by embellishment. . . Amplification is of the greatest effect, and excellence in it the pecu-

\footnotetext{
s2 Ibid., I, p. 403.

Cicero, p. 270.

${ }^{2}$ Adams, II, p. 4.
} 
liar and appropriate praise of the orator," ${ }^{34}$ he exclaims. In the same strain, Adams says, "The object of amplification is to magnify-one of those ornaments which rhetoric borrows from poetry." 35 On this point, the two men are entirely agreed, and we may conclude, without stretching our imagination, that Adams has borrowed very largely from Cicero.

The last stage in writing a composition of any kind is, or rather, ought to be, embellishment, according to rhetoricians. This process of finishing and polishing involves composition, elegance, dignity, and figurative language.

To continue the classification, composition includes order, juncture, and number. In ancient times, when the Latin language, with its rhythm, its measured syllables, and its very flexible endings, was the language of the people, it was possible to determine rules for putting words in a harmonious order, or for obtaining a definite balance in the sentence. The American language, on the contrary, is very stiff, and can not be handled as easily, so that the whole discussion of order, juncture and number is useless to an American student, except as the knowledge might prove interesting. Adams realized this fact, but he clung so closely to the Ciceronian doctrines that he could not resist the temptation, and he relates the whole Latin system, just as Cicero gave it. A very large part of the second volume of the Lectures is therefore entirely useless to a student of rhetoric. This is a splendid example of the influence of the ancient on the modern rhetorician.

Purity and perspicuity may be considered together, for they are both used for the same purpose. Here the two men have more in common, or rather, Cicero's work is modern enough for Adams to copy without so much discredit. Some of the discussion here is quite modern. "Avoid strangeness of outlandish pronunciation,"36 says Cicero, and Adams agrees. Again, we are told to use words in common use, and such as aptly express what we wish to communicate or explain, "without any ambiguous word or phrase, not making our sentences too long, not making such observations as are drawn from other subjects for the sake of comparison too prolix; avoiding all incoherency of thought, reversion of the order of time,

\footnotetext{
Cicero, p. 362 .

Adams, II, p. I25.

${ }^{*}$ Cicero, p. 344 .
} 
all confusion of persons, all irregularity of arrangement whatever." Adams says, "That choice of words must be the best, which most effectually conveys his idea to the mind of his hearer." ${ }^{\text {ss }}$ This rule, he continues, will keep out new words, because an explanation will be necessary to understand them; it will keep out old words, because the audience will have forgotten their significance; it will keep out foreign words, because the "generality of mankind speak but one language." be intelligible, well-chosen, and must express what they are supposed to express without any ambiguity. In only one place do the two disagree. Cicero says that unusual words, which have gone out of use in daily speech, give a certain dignity when used occasionally. Also, he says that new words, formed by the speaker, are very effective once in a while. However, he would have the speaker use only such obsolete words as are choice and ornamental, and have some fullness of sound. ${ }^{40}$ In general, though, Adams has based his lecture on what Cicero has said.

Figurative language is the last process to be used in the embellishment of the discourse. Here we find that the proportion of times that Adams has copied is much less than in any other part of the books. To be sure, he would have found it very difficult to do so, for the discussion in the Oratore is anything but clear to anyone who is familiar with modern expressions. For instance, Cicero uses the term metaphor to cover all the figures of speech that we distinguish between so carefully now, and his rules may apply to one metaphor, or they may not. This is very confusing, and Adams wisely ignores this chapter, and gives a modern interpretation of the subject.

Such comparison as it has been possible to make in the limited space at my disposal, has necessarily been brief and cursory. Such as it is, however, it has tended to establish a few facts. The big thing that constantly impresses us is that Adams had a most profound respect for Cicero, and almost never lost an opportunity to quote his arguments. Occasionally he differs from him a little, once or twice flatly contradicting him. A few times, he adds a

\footnotetext{
"I Ibid., p. 345 .

* Adams, II, P. I5\%.

Ibid., II, D. I5\%.

- Cicero, D. 375 .
} 
little to what the older rhetorician has said, but his additions are generally weak.

Cicero's treatise is necessarily out of date, especially so in such discussions as the church. Such institutions have undergone an important change in the generations that have passed since Cicero's death. Such changes, Adams has ignored many times. When he does consider them, his discussion is much freer, and much more worthy of him.

Some people would attempt to justify Adams on the ground that such a course as he offered might be expected to cover mainly the history of oratory. To these, I would reply that the Oratore of Cicero is not an epitome of the history of oratory; that Cicero and Quintilian together are not responsible for all that has ever been given to the science or art of rhetoric. I can only repeat what I have said many times already, that there is no apparent excuse for the wholesale copying of which Adams is guilty. 